\title{
Ichneumonid parasitoids (Hymenoptera: Ichneumonidae) reared in North Europe from pupae of Chelis puengeleri (Bang-Haas, 1927) (Lepidoptera: Erebidae, Arctiinae)
}

\author{
Veli Vikberg, Kari Nupponen, Timo Nupponen, Pekka Savolainen, Kari Tahvanainen, \\ Jukka Tiittanen \& Matthias Riedel
}

Vikberg, V., Nupponen, K., Nupponen, T., Savolainen, P., Tahvanainen, K., Tiittanen, J. \& Riedel, M. 2019: Ichneumonid parasitoids (Hymenoptera: Ichneumonidae) reared in North Europe from pupae of Chelis puengeleri (Bang-Haas, 1927) (Lepidoptera: Erebidae, Arctiinae). — Entomol. Fennica 30: 138-144. https://doi.org/10.33338/ef.84150

Four ichneumonid species were reared for the first time from pupae of Chelis puengeleri in North Europe. One female of Pimpla sodalis Ruthe, 1859 (Pimplinae) was reared in Cievrracohkka, N Sweden in July 2012. One male of Ichneumon formosus Gravenhorst, 1829 (Ichneumoninae) was reared in Nissuntjårro, Torne Lappland, Sweden in July 2012. One male of Ichneumon vafer Tischbein, 1876 (Ichneumoninae) was reared in July 1999 in the Iremel Mountain reserve, Baskiria, South Ural, Russia. Two females and one male of Ichneumon holoarctiae Riedel et Vikberg sp. n. (Ichneumoninae) were reared in June and July 2004 and 2012 in Finnmark, North Norway.

V. Vikberg, Liinalammintie 11 as. 6, FI-14200 Turenki, Finland; e-mail: veli.vikberg@pp.inet.fi

K. Nupponen, Merenneidontie 19 D, FI-02320 Espoo, Finland; e-mail: Kari.Nupponen@kolumbus.fi

T. Nupponen, Staffanintie 10 A, FI-02360 Espoo, Finland; e-mail: Timo.Nupponen@capgemini.com

P. Savolainen, Mäkirinne 11 A1, 70820 Kuopio, Finland

K. Tahvanainen, Kartanontie 32 as. 1, 04410 Järvenpää, Finland; e-mail: kari.tahvanainen@valmet.com

J. Tiittanen, Lammaskallionkatu 3A 10, 18150 Heinola, Finland; e-mail: jukka_tiittanen@hotmail.com

M. Riedel, Zoologische Staatssammlung München, Münchhausenstr. 21, D81247 München, Germany, e-mail: mamaflo.riedel@t-online.de

Received 2 January 2017, accepted 1 October 2018

\section{Introduction}

As a result of a recent phylogenetic study of the subtribe Arctiina (Rönkä et al. 2016), the arctiine genus previously well-known as Holoarctia Ferguson, 1984 (Lepidoptera: Erebidae, Arctiinae) was synonymized with Chelis Rambur, 1866. The genus is represented by two species in Europe: the type species of the genus Holarctia, $C$. cervini (Fallou, 1864) in the Alps, and C. puengeleri (Bang-Haas, 1927) in northern Europe (Pöyry \& Kullberg 1997). Chelis puengeleri has a 
wide but disjunct Holarctic distribution, and the taxon is divided into several subspecies. The nominate subspecies, C. puengeleri puengeleri, is known from the Sayan, the Hamar-Daban and the Stanovoi Mountains in Southern Siberia. The North European subspecies, C. puengeleri fridolini (Torstenius, 1971), is distributed through arctic Asia to Alaska. The subspecies C. puengeleri iremelica Dubalov, 2007 occurs at high altitudes in a restricted area of the southern Ural Mountains, Russia. This rare moth lives on almost bare areas of fjelds at $600-1,400 \mathrm{~m}$ above sea level. Eggs, larvae, cocoons and pupae can be found under stones (Silvonen et al. 2014).

Hitherto no parasitoids have been recorded from Chelis (as Holoarctia) puengeleri, but two ichneumonids have been reared from pupae of Chelis cervini (Horstmann 2001). In this article, we report four ichneumonid species, which we have reared from pupae of $C$. puengeleri in Norway, Sweden and southern Ural, Russia. One of them is described as new to science.

\section{Materials and methods}

\subsection{Excursions}

Excursions to the localities where pupae of $C$. puengeleri were found are as follows:

- Norway, Finnmark, Porsanger: P. Savolainen, $\mathrm{K}$. Tahvanainen and J. Tiittanen have made several excursions to the area. Many pupae of C. puengeleri were found, but only one male of the moth and one parasitoid were reared (in 2012).

- Russia, Baskiria, Iremel Mountain reserve: Four excursions to the area were made during 23.-27.VI.1996 and 11.-14.VII.1997 by K. Nupponen et. al., 25.-27.VI.1999 by T. \& K. Nupponen and 16.-17.VI.2001 by K. Nupponen (Nupponen \& Fibiger 2002). Altogether about 40 adults of $C$. puengeleri were reared from pupae, but only a single parasitoid emerged (from a pupa found 25.VI.1999).

- Sweden, Torne Lappmark, Nissuntjårro: Two collecting trips were made during 29.-30.VI. 2009 by T. and K. Nupponen and 4.-5.VII. 2012 by T. Nupponen. Altogether about 70 adults of $C$. puengeleri were reared from pupae, but only a single parasitoid emerged (from the 2012 rearings).

- Sweden, Torne Lappmark, Karmatschokka: P. Savolainen, K. Tahvanainen and J. Tiittanen made two collecting trips to the area in 2015. They found some 20 larvae and some 220 pupae of $C$. puengeleri, most of which were already empty. Some 20 pupae were parasitized (one ichneumonid was reared) and just one male and one female of C. puengeleri were reared.

A typical habitat of the host moth, C. puengeleri, is shown in Fig. 1.

\subsection{Examination of the reared ichneumonid specimens}

The reared ichneumonid specimens were studied and identified by V. Vikberg and M. Riedel. The photographs were taken by P. Malinen and M. Riedel and they were included in the photo archieves Kotka of the Finnish Natural History Museum, where their details can be examined by zooming in. The links to the photos in Kotka are given under each species. The specimens will be deposited in the zoological collection (MZH) of the Finnish Natural History Museum, Helsinki, the Zoologische Staatssammlung Munich (ZSM) and the personal collection of M. Riedel.

The following abbreviations are used:

- POL: Postocellar line, measured as the distance between the inner margins of the lateral ocelli.

- OOL: Ocello-ocular line, measured as the distance between the outer margin of one lateral ocellus and the inner margin of the compound eye of the same side.

- OD: Ocellar diameter, measured as the maximum width of one lateral ocellus.

DNA barcodes for one specimen of Ichneumon holoarctiae, one specimen of I. vafer, one specimen of I. formosus and one specimen of Pimpla sodalis were analysed within the framework of the Finnish Barcode of Life project. The sequenc- 


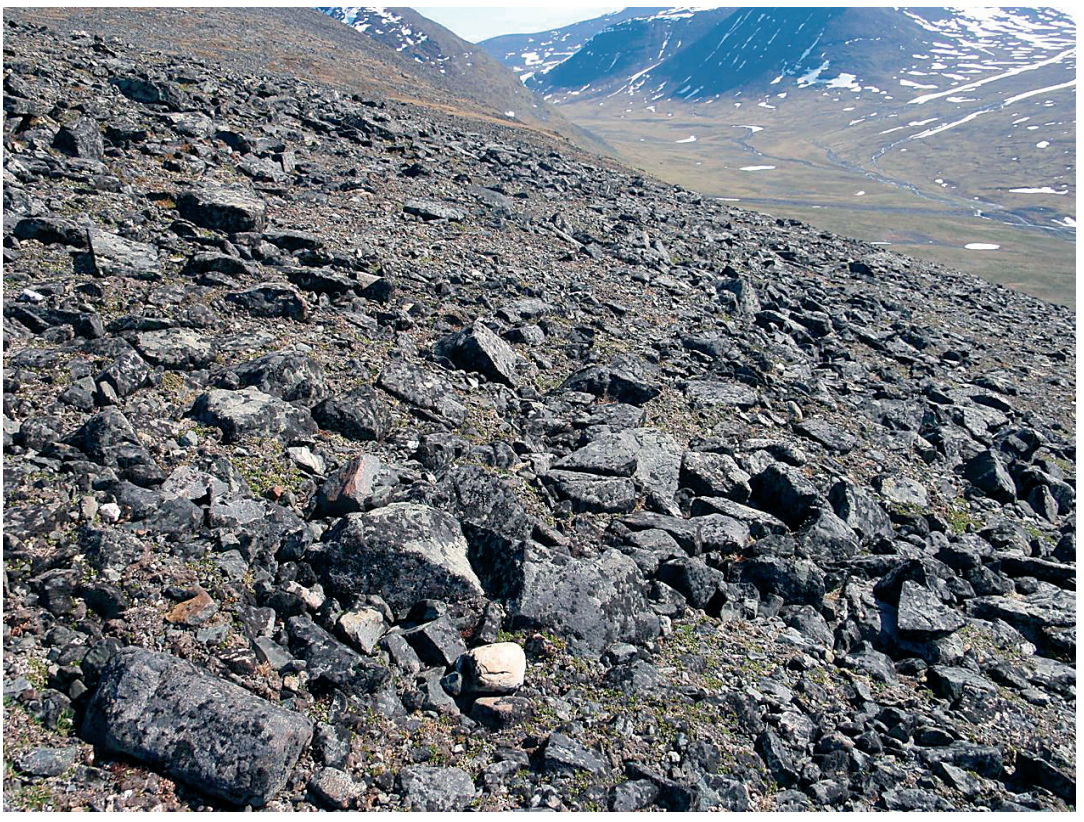

Fig. 1. Habitat of Chelis puengeleri in Swedish Lapland, Abisko. Photo taken on 29.VI.2009 by K. Nupponen. ing was carried out in the Canadian Centre for DNA Barcoding (CCDB, Biodiversity Institute of Ontario, University of Guelph) following the protocols shown at: http://www.dnabarcoding. $\mathrm{ca} / \mathrm{pa} / \mathrm{ge} /$ research/protocols. Full COI sequence information, including GenBank accession numbers, collection data and voucher images, are publicly available in BOLD and can be accessed under dx.doi.org/10.5883/DS-ICHPUE.

\section{Ichneumonid species reared from Chelis puengeleri}

\subsection{Pimpla sodalis Ruthe, 1859 (Pimplinae)}

One female of $P$. sodalis was reared on 2.VII. 2015 from a pupa of $C$. puengeleri in Cievrracohkka, Swedish Lapland by P. Savolainen and $\mathrm{K}$. Tahvanainen (in MZH). DNA-barcoding of the reared female confirmed its identification. The body of the female is $8.9 \mathrm{~mm}$ long, fore wing $7.2 \mathrm{~mm}$, ovipositor sheath $2.8 \mathrm{~mm}$, of which 2.4 $\mathrm{mm}$ projects beyond the apex of the metasoma. Width of the head is $1.61 \mathrm{~mm}$. The filiform antennae have 36 flagellomeres.

Link to photos of the reared female: http:// id.luomus.fi/GL.7183.

The female was identified by using the key in
Kasparyan (1981). Both sexes of $P$. sodalis were originally described from Iceland (Ruthe 1859).

Pimpla sodalis has a wide holarctic distribution (Yu et al. 2016) and it occurs in arctic areas and further south in mountains. In the Alps, it occurs usually above timberline up to 3,000 $\mathrm{m}$ a.s.l. A long series of $P$. sodalis was reared from $C$ helis cervini (Erebidae: Arctiinae) in two localities at high altitudes (about 3,000 m a.s.1.) of the Alps: Zermatt, Valais (Switzerland) and Ötztal, Nordtirol (Austria) (Horstmann 2001). No specimens of Pimpla hirsuta Strobl, a closely related species occurring high in the Alps, were among those reared from this arctiine moth. In Finnish Lapland, the incidence of the otherwise rare $P$. sodalis rose distinctly during a calamitous outbreak of Epirrita autumnata (Borkhausen) (Geometridae) on birches on a subarctic fell (Nuorteva \& Jussila 1967, as Coccygomimus).

The recorded hosts of $P$. sodalis belong to five families of Lepidoptera: Nymphalidae, Geometridae, Erebidae, Noctuidae and Pyralidae (Horstmann 2001).

\subsection{Ichneumon formosus Gravenhorst, 1829 (Ichneumoninae)}

One male of Ichneumon formosus was reared from a pupa of $C$. puengeleri in Nissuntjårro, 
600-800 m, Torne Lappmark, Sweden by T. Nupponen (in $\mathrm{MZH}$ ). The pupa of $C$. puengeleri fridolini (Torstenius) was found on 4.VII.2012, and the parasitoid emerged on 21.VII.2012. The body of the male is $14 \mathrm{~mm}$ long, the length of the fore wing is $10.7 \mathrm{~mm}$ and the width of the head is $2.35 \mathrm{~mm}$. The bristle-shaped antennae have 40 flagellomeres, with tyloids on 6-19.

Link to photos of the reared male: http:// id.luomus.fi/GL.7182.

The male was identified by using the key to males of Ichneumon in Hilpert (1992). DNAbarcoding showed that the reared male is close to the only named earlier specimen of Ichneumon formosus.

The colouration of the present male differs slightly from the description given by Hilpert (1992): the face and scapus are completely black, the hind femur is black but yellow-red in basal $1 / 10$, the hind tarsus is completely yellow and scutellum and pterostigma are yellow.

The species is divided into two subspecies (or forms, see Hilpert 1992): Ichneumon formosus formosus Gravenhorst and I. formosus microcephalus Stephens, 1835. The reared male has the $2^{\text {nd }}$ and $3^{\text {rd }}$ tergites extensively red and on those grounds probably belongs to the nominate subspecies, although its face is entirely black - a rare variety (in one of 220 males) found in Ichneumon formosus microcephalus but none among 180 studied males of the nominate form (Hilpert 1992).

Among its recorded hosts are Euphydryas maturna (Linnaeus, 1758) (Grönblom 1964), Phragmatobia fuliginosa (Linnaeus, 1758) (Grönblom 1964, Hinz 1998, Hinz \& Horstmann 2007), Parasemia plantaginis (Linnaeus, 1758) (Meyer 1933) and Bupalus piniarius (Linnaeus, 1758) (Meyer 1933). Although literature records are open to suspicion, it appears to be a regular parasitoid of at least one arctiine. In culture, overwintered females have been recorded to oviposit in the pupa of Ph. fuliginosa inside its cocoon, and both the ichneumonid and the host have one generation per year (Hinz \& Horstmann 2007) or Ph. fuliginosa is widely bivoltine.

\subsection{Ichneumon vafer Tischbein, 1876 (Ichneumoninae)}

One male was reared from a pupa of $C$. puengeleri in the Iremel Mountain reserve, Bashkiria, $1,300 \mathrm{~m}$ a.s.1., South Ural $\left(54.5^{\circ} \mathrm{N} 58.8^{\circ} \mathrm{E}\right)$, Russia by T. and K. Nupponen (in MZH). The pupa was found on 25.VI.1999 and the male emerged on 13.VII.1999. The habitat is dry mountain tundra.

Link to photos of the reared male: http:// id.luomus.fi/GL.7181

Remarks. In the key to Ichneumon males by Hilpert (1992), this species runs to Ichneumon vafer Tischbein, but differs slightly from the description given by Hilpert (1992): hind femur is narrowly reddish yellow basally and the $2^{\text {nd }}$ and $3^{\text {rd }}$ tergites are black with chestnut-red colouration basally and laterally. DNA-barcoding of the reared male unfortunately failed. It is provisionally regarded as an aberrant male of $I$. vafer and its characters are described below.

Description of the male. Body length $16 \mathrm{~mm}$, length of fore wing $11 \mathrm{~mm}$, width of head 2.52 $\mathrm{mm}$. Flagellum with 41 flagellomeres; $1^{\text {st }}$ flagellomere length $2.2 \times$ width. Tyloids on flagellomeres 6-16, long-oval, maximal length 0.7 of their flagellomeres, situated basally. Head covered with brownish setae. Temple strongly and roundly narrowed behind eye. OOL $1.2 \times$ OD. Frons, face and clypeus rugose-punctate. Malar space length $0.6 \times$ width of mandibular base.

Mesosoma covered with brownish setae. Mesoscutum closely punctate and finely granulate, more or less shining. Mesopleuron and metapleuron rugose-punctate, metapleuron partly striate. Scutellum moderately elevated, punctate and granulate, without lateral carina. Propodeum with square area superomedia; spiracles slit-shaped; dentiparal edge with small stout tooth. Hind coxa ventrally rugose-punctate. Hind femur densely punctate, length $4.2 \times$ height. Fore metatarsus with a small apical tooth.

Postpetiolus strongly widened, median field with fine aciculation. $2^{\text {nd }}$ tergite length $0.83 \times$ width. Gastrocoelus strongly impressed, with longitudinal ribs; thyridia oblique, $0.8 \times$ as wide as interval between them. $2^{\text {nd }}$ to $5^{\text {th }}$ tergites densely punctate and granulate, matt; $6^{\text {th }}$ and $7^{\text {th }}$ tergites with superficial punctures, shining. 
Colour black, including flagellum, head and mesosoma. Metasoma black; $2^{\text {nd }}$ and $3^{\text {rd }}$ tergites chestnut-red anteriorly and laterally. Coxae, trochanters and femora black; fore and middle femora reddish apically, hind femur with a narrow reddish-yellow basal ring. Legs otherwise reddish-yellow; hind tibia infuscate in apical 1/4; distal hind tarsomere brownish. Wings hyaline, pterostigma yellow.

Distribution and hosts. Ichneumon vafer has a rather wide distribution in Europe. Its synonym $I$. conjugalis Holmgren was described from Sweden, I. rogenhoferi Kriechbaumer from Italy and I. quartanus Perkins from England. It has been recorded from European Russia as I. rogenhoferi by Rasnitsyn and Siytan (1981). The lectotype of $I$. rogenhoferi was reared from Parasemia plantaginis (as Arctia pl.). It has been experimentally reared from Parasemia plantaginis (Hinz 1998, Hinz \& Horstmann 2007). The overwintered female oviposited eggs in pupae of $P$. plantaginis inside its cocoons. An interesting old rearing record is that from Chelis simplonica (Anderregg in Boisduval. 1840) by Dittrich (1909).

\subsection{Ichneumon holoarctiae Riedel et Vikberg, sp. n. (Ichneumoninae) Figs 2-3}

Type material. Holotype: Female, Norway, Porsanger, EIS 174 FN, 29.VI.2004, J. Engdal leg., ex pupa of C. puengeleri 20.VII.2004 (ZSM). Paratypes: Female, data as in holotype (coll. Riedel); male Norway, Finnmark, Porsanger, 7.VII.2012, K. Tahvanainen leg., ex pupa of $C$. pungeleri in (MZH).

Link to photo of pupa of $C$. puengeleri from which the male of I. holoarctiae emerged: http:// id.luomus.fi/GL.7179. Link to photos of the reared male: http://id.luomus.fi/GL.7180

Description. Female: Body length 11.5 (holotype) or 13 (paratype) mm; fore wing 8.2 (holotype) and 9.5 (paratype) mm. Antenna with 39 (holotype) and 41 (paratype) flagellomeres, slightly lanceolate; $1^{\text {st }}$ flagellomere length $1.7 \times$ width, $5^{\text {th }}$ to $7^{\text {th }}$ flagellomeres square; widest flagellomeres $1.4 \times$ wider than long; preapical flagellomere $0.7 \times$ as long a wide.

Temple long, slightly and roundly narrowed behind eye, about as wide as eye. OOL $1.3 \times$ OD.

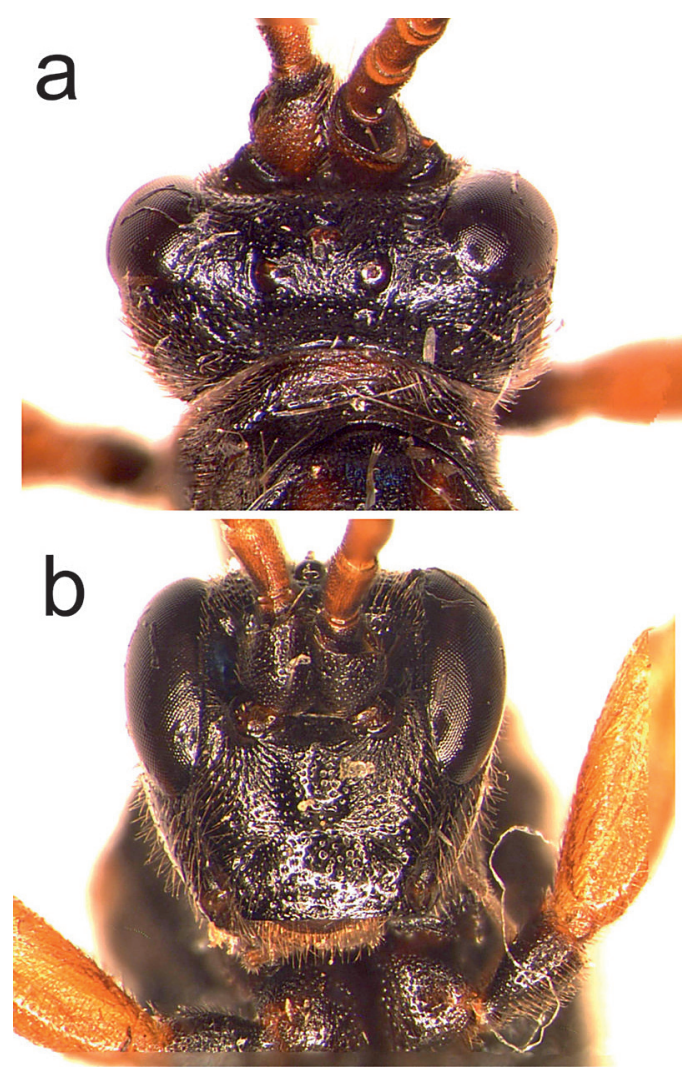

Fig. 2. Head and face of Ichneumon holoarctiae sp. n. holotype. - a. Head in dorsal view. - b. Face in anterior view.

Frons rugose-punctate. Face and clypeus with dense punctures, central face partly rugose. Gena in ventral $1 / 3$ with scattered punctures. Malar space long, length $1.3 \times$ width of mandibular base. Genal carina reaching hypostomal carina far from mandibular base; hypostomal carina slightly elevated.

Mesosoma with fine pale brownish setae. Side of pronotum with fine punctures in dorsal $1 / 3$, with striation in ventral $2 / 3$. Notaulus indistinct. Mesoscutum closely punctate and shining. Mesopleuron densely punctate, with striation in caudal half; metapleuron completely punctulostriate; coxal carina present. Scutellum flat, as long as wide, with scattered punctures, not carinate laterally. Propodeum with square area superomedia, costula indistinct; spiracles slitshaped. Hind coxa densely rugose-punctate ventrally, without scopa or sharp edge. Hind femur densely punctate, but punctures in ventral $1 / 5 \mathrm{su}-$ 
perficial and scattered, length $4.0 \times$ height. Tarsomeres slightly widened; $3^{\text {rd }}$ tarsomere of middle leg some $1.6 \times$ longer than wide.

Areolet pentagonal, anterior distance of intercubiti $1-2 \times$ their diameter; nervulus slightly postfurcal.

Metasoma strongly oxypygous, stout. Postpetiolus strongly widened; median field with fine aciculation. $2^{\text {nd }}$ tergite length $0.65 \times$ width. Gastrocoelus slightly impressed, with fine longitudinal ribs; thyridia small, transverse, $0.7 \times$ as wide as interval between them. $2^{\text {nd }}$ and $3^{\text {rd }}$ tergites densely punctate and granulate, matt; following tergites with superficial punctation and fine granulation, more or less shining. Ovipositor sheath not surpassing metasomal apex.

Colour black. Flagellum with basal 11 flagellomeres dark reddish, apically black. Head black. Mesoscutum chestnut-red, with diffuse blackish median stripe. Scutellum blackish (paratype) or with chestnut-red spot (holotype). Tegula reddish; pronotum completely black. $2^{\text {nd }}$ tergite reddish, with apico-median blackish mark. $6^{\text {th }}$ and $7^{\text {th }}$ tergites with small apical ivory spots (on $6^{\text {th }}$ tergite smaller than on $7^{\text {th }}$ tergite in holotype). Coxae and trochanters black. Legs including trochantelli otherwise reddish; distal tarsomeres more or less brownish. Wings hyaline, pterostigma yellowish.

Male: Length of body $13 \mathrm{~mm}$, fore wing 11.2 $\mathrm{mm}$. Antenna about $9.3 \mathrm{~mm}$.

Left antenna with 40 flagellomeres (right antenna missing), $1^{\text {st }}$ flagellomere length $2.1 \times$ width in lateral view, $2^{\text {nd }}$ flagellomere length $1.3 \times$ width, $10^{\text {th }}$ flagellomere about square. Narrow, oval tyloids on flagellomeres 5-16(17), on flagellomere 12 its size $0.15 \times 0.07 \mathrm{~mm}$ and situated basally and leaving apical 0.2 free.

Head $0.86 \times$ as high as wide. In dorsal view $1.7 \times$ as wide as long, temple slightly longer than eye, narrowing and slightly rounded apically, covered with long dark setae directed towards eyes. POL $1.23 \times$ as wide as OOL, OOL $1.75 \times$ OD. Temple maximally $1.08 \times$ as long as eye width. Malar space $0.88 \times$ as long as width of mandibular base. Mandible with two apical teeth, almost parallel, lower $0.25 \times$ as long as upper tooth. Scutellum strongly convex, its highest point anterior to middle. Area superomedia fused with area basalis, combined cell broadest anteri-

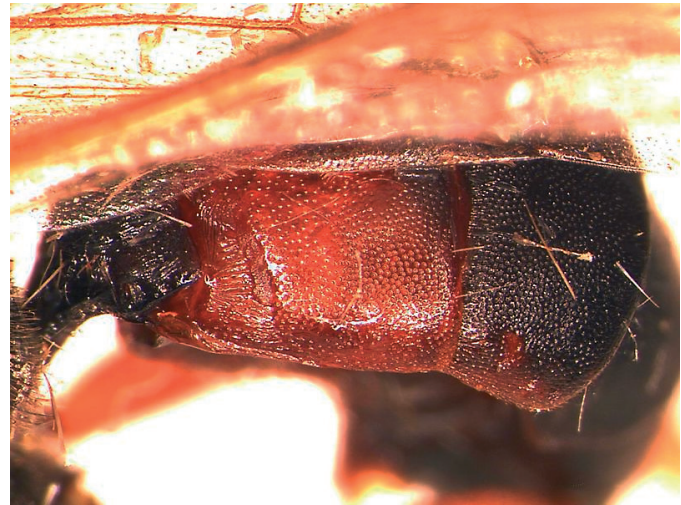

Fig. 3. Basal part of metasoma of Ichneumon holoarctiae sp. $\mathbf{n}$. holotype.

orly $(0.80 \mathrm{~mm})$, its length 0.75 and breadth posteriorly $0.65 \mathrm{~mm}$. Hind wing with $17-18$ distal hooks.

Postpetiolus distinctly aciculate, very broad ( $3.2 \times$ as wide as long, its length measured as distance between spiracle and hind margin), broadest point near posterior margin.

Length of $2^{\text {nd }}$ tergite medially $0.64 \times$ length of its maximum width. Area between gastrocoeli distinctly aciculate, $1.06 \times$ as wide as one gastrocoelus, which is short. Thyridia distinct, rather weak, about $0.9 \times$ as wide as interval between them. $2^{\text {nd }}$ sternite with rounded fold (artifact?), $3^{\text {rd }}$ sternite with indistinct fold, $4^{\text {th }}$ sternite without distinct fold (artifact?). Apical margin of hypopygium slightly produced medially, rounded.

Colour black. Apical half of mandible reddish brown. Palpi brownish yellow, basal joint of maxillary palpus and whole labial palpus infuscate. Pterostigma brownish yellow. Femora brownish red, basal 0.6 of fore and basal 0.75 of mid-femur black on underside; hind femur black, with basal 0.2 and apical 0.07 red. $2^{\text {nd }}$ tergite red, with large blackish area medially and posteriorly. Lateral margin of $3^{\text {rd }}$ tergite with narrow red area. $2^{\text {nd }}$ to $4^{\text {th }}$ sternites reddish, slightly infuscated medially.

Etymology. The specific name was derived from the earlier name of the host genus, Holoarctia.

Taxonomic remarks. In the key of Hilpert (1992), the females of this new taxon run to Ichneumon thomsoni Holmgren, which is known from Scandinavia. They differ from I. thomsoni 
by slenderer $1^{\text {st }}$ flagellomeres, slenderer hind femur, black pronotum, completely black petiolus and black $3^{\text {rd }}$ tergite. The male runs to boreomontane Ichneumon nigroscutellatus Kriechbaumer, 1897 in the key to males (Hilpert, 1992) but differs mainly by the reduced red colouration of the metasoma.

Whether the male is conspecific with the females at all is somewhat questionable. The material was sent for DNA-barcoding, but barcoding of the females revealed no useful results. Therefore, the matter should be verified by additional material in the future.

Because the $4^{\text {th }}$ sternite of the reared male has no clear medial fold, the author V. V. first supposed that it could belong to the genus Diphyus Kriechbaumer. However, DNA-barcoding showed that its nearest earlier named species was Ichneumon intricator Wesmael.

\section{Discussion}

In this article, four species of Ichneumonidae are reported for the first time reared from Chelis puengeleri. However, only a few specimens of each parasitoid were available. Thus, further rearings are needed to get a better idea about the ichneumonid and other parasitoids feeding on that rare arctic moth. In the future, it would be helpful to study more females of the reared species of Ichneumoninae. In the subfamily Ichneumoninae, females often have better morphological characters for an unequivocal identification than the corresponding males.

Acknowledgements. Pekka Malinen took most photographs of the ichneumonids and helped to put them in Kotka. Marko Mutanen and Juho Paukkunen helped with DNA-barcoding of the specimens. Mark R. Shaw made valuable comments on the two drafts of the manuscript.

\section{References}

Dittrich, R. 1909: Hymenopterologische Bemerkungen. - Jahresheft des Vereins für Schlesische Insektenkunde 2: 38-46. [In German.]

Dubatolov, V. V. 2007: New tiger moth taxa from Eurasia (Lepidoptera, Arctiidae). - Atalanta 38(3/4): 351359.

Grönblom, T. 1964: Einige aus Schmetterlingszuchten hervorgegangene Schlupfwespen (Hym., Ichneumo- noidea). - Annales Entomologici Fennici 30: 104111.[In German.]

Hilpert, H. 1992: Zur Systematik der Gattung Ichneumon Linnaeus, 1758 in der Westpalaearktis (Hymenoptera, Ichneumonidae, Ichneumoninae). - Entomofauna Supplement 6: 1-389. [In German.]

Hinz, R. 1998: Zucht einiger Ichneumon-Arten aus ihren Wirten I. (Hymenoptera, Ichneumonidae). - Entomofauna 19 (30): 493-500. [In German.]

Hinz, R. \& Horstmann, K. 2007: Über Wirtsbeziehungen europäischer Ichneumon-Arten (Insecta, Hymenoptera, Ichneumonidae, Ichneumoninae). - Spixiana 30(1): 39-63. [In German.]

Horstmann, K. 2001: Revisionen von Schlupfwespen-Arten V (Hymenoptera: Ichneumonidae). — Mitteilungen der Münchener Entomologischen Gesellschaft 91: 77-86. [In German.]

Kasparyan, D. R. 1981: [A guide to the insects of the European part of the USSR, Ichneumonidae, subfamily Pimplinae (Ephialtinae).]. — Opredeliteli Faune SSSR 3(3): 41-97. [In Russian.]

Meyer, N. F. 1933: Keys to parasitic Hymenoptera (family Ichneumonidae) of the USSR and adjacent countries. Vol. 1. Introduction and Ichneumoninae. - Zoological Institute of the Academy of Sciences of the USSR 9(1): 1-438. Translated from Russian, Israel Program for Scientific Translations, Jerusalem 1968.

Nuorteva, P. \& Jussila, R. 1967: Seasonal and zonal distribution of Ichneumonidae (Hym.) on a subarctic fell during a calamity of the geometrid moth Oporinia autumnata (Bkh.) on birches. - Annales Entomologici Fennici 33: 155-163.

Nupponen K. \& Fibiger M. 2002: Contribution to the knowledge of the fauna of Bombyces, Sphinges and Noctuidae of the Southern Ural Mountains, with description of a new Dichagyris (Lepidoptera: Lasiocampidae, Endromidae, Saturniidae, Sphingidae, Notodontidae, Noctuidae, Pantheidae, Lymantriidae, Nolidae, Arctiidae). — Phegea 30(4): 121-185.

Pöyry, J. \& Kullberg, J. 1997: Taxonomic revision of Holoarctia, Ferguson 1984 (Arctiidae). - Nota Lepidopterologica 20(1/2): 45-65.

Rasnitsyn, A. P. \& Siytan, U. V. 1981: [A guide to the insects of the European part of the USSR, Ichneumonidae, subfamily Ichneumoninae]. - Opredeliteli Faune SSSR 3(3): 505-636. [In Russian.]

Rönkä, K., Mappes, J., Kaila, L. \& Wahlberg, N, 2016: Putting Parasemia in its phylogenetic place: a molecular analysis of the subtribe Arctiina (Lepidoptera). Systematic Entomology 41(4): 844-853. doi: https:// doi.org/10.1111/syen.12194

Silvonen, K., Top-Jensen, M. \& Fibiger, M. 2014. Suomen päivä- ja yöperhoset - maastokäsikirja. (A field guide to the butterflies and moths of Finland). Östermarie, Denmark. 820 pp. [In Finnish.]

Yu, D.S.K., Achterberg van, C. \& Horstmann, K. 2016 : World Taxapad 2016, Ichneumonoidea. Taxonomy, Biology, Morphology and Distribution. On USB flash-drive. www.taxapad.com, Nepean, Ontario, Canada. 